\title{
ANALISIS PENGARUH JADWAL KULIAH MALAM, STATUS BEKERJA DAN LINGKUNGAN KELAS TERHADAP TINGKAT KONSENTRASI KEGIATAN BELAJAR MENGAJAR MAHASISWA TEKNIK INDUSTRI UNIVERSITAS RIAU KEPULAUAN
}

\section{ANALYSIS OF EFFECT OF COLLEGE NIGHTSCHEDULE, WORKING STATUS, AND CLASS ENVIRONMENTTO THE CONCENTRATION OF INDUSTRIAL ENGINEERING STUDENT IN RIAU KEPULAUAN UNIVERSITY}

\author{
Vera Methalina Afma \\ (Prodi Teknik Industri, FakultasTeknik, Universitas Riau Kepulauan, Indonesia \\ 1 e-mail: vera.afma @gmail.com
}

\begin{abstract}
Abstrak
Penelitian ini bertujuan untuk mengetahui dan menganalisa pengaruh jadwal perkuliahan malam, status bekerja dan lingkungan kelas terhadap tingkat konsentrasi mahasiswa Teknik Industri di Universitas Riau Kepulauan.Pada penelitian ini, variabel yang akan diteliti adalah faktor kelelahan mahasiswa, status bekerja dan lingkungan kelas terhadap tingkat konsentrasi mahasiswa. Data pada penelitian ini diperoleh melalui kuesioner persepsi dan kuesioner Standford Sleepiness Scale. Kuesioner akan disebarkan kepada 80 orang mahasiswa Teknik Industri Universitas Riau Kepulauan. Dari hasil penelitian dapat disimpulkan bahwa jadwal kuliah malam tidak berpengaruh padatingkat konsentrasi mahasiswa dalam belajar, status bekerja tidak berpengaruh pada tingkat konsentrasi mahasiswa, lingkungan kerja berpengaruh pada tingkat konsentrasi mahasiswa, dan jadwal kuliah malam, status bekerja dan lingkungan kerjasamasamaberpengaruhterhadaptingkatkonsentrasimahasiswa.Adapun luaran yang diharapkan dari penelitian ini adalah jurnal penelitian ilmiah Dimensi Universitas Riau Kepulauan atau Jurnal Profisiensi Program Studi Teknik Industri Universitas Riau Kepulauan dan pengayaan bahan ajar pada mata kuliah Ergonomi
\end{abstract}

Kata Kunci;jadwalkuliah, status bekerja, lingkungan, Standford Sleepiness Scale

\begin{abstract}
The aim of this study is to identify and analyze the effect of learning night schedule, working status and class environment to the concentration of Industrial Engineering students at the Riau KepulauanUniversity. The variables are fatigue factor of student, working status and class environment. The method in this study areperception questionnaires and Stanford Sleepiness Scale that will be distributed to 80 person of Industrial Engineering students of Riau KepulauanUniversity.The results of this study are schedule is not effect to the concentration of students, work status is not effect to the concentration of students, working environment iseffect to the concentration of students, and schedules, working status and the class environment is together effected to the concentration of students. The expected outcomes of this study is journal Dimensi of Riau KepulauanUniversitasor JournalProficiency of Industrial Engineering Program, Riau KepulauanUniversity and Ergonomic teaching materials.
\end{abstract}

Keywords :schedule, working status, class environment, Standford Sleepiness Scale Questionnaires 


\section{PENDAHULUAN}

Kota Batam yang terkenal sebagi kota industry memang sangat berpengaruh terhadap kegiat anak ademik terutama untuk jenjang pendidikan diploma dan sarjana. Mahasiswa yang kuliah rata-rata adalah pekerja di siang hari, dan memanfaatkan waktu di malam hari untuk kuliah. Pada program studi Teknik Industri, dari 250 orang mahasiswa, 80\% adalah pekerja di industri yang ada di Kota Batam dengan jam kerja di pagi hari. Sehingga, kegiatan perkuliahan yang terjadi di Universitas Riau Kepulauan juga dilaksanakan pada malam hari. Jam belajar yang diterapkan adalah malam hari mulai dari pukul 17.30-22.00 WIB.

Dari hasil pengamatan awal yang peneliti lakukan terhadap mahasiswa Jurusan Teknik Industri Fakultas Teknik, penulis menduga bahwa mahasiswa yang dating kuliah terlihat kelelahan dan terkadang kurang menangkap apa yang diajarkan oleh dosen. Selain itu juga, suasana lingkungan yang tidak kondusif pada saat proses belajar mengajar. Dari pengamatan awal ini, maka peneliti tertarik untuk melakukan penelitian untuk mengetahui pengaruh jadwal kuliah malam, status bekerja atau tidak dan lingkungan terhadap kegiatan belajar mengajar. Dari hasil penelitian ini nantinya akan memberikan masukan kepada dosen dalam hal cara dan penyiapan materi dalam proses belajar mengajar.

Beberapa penelitian terdahulu yang menjadi landasan dalam penelitian ini adalah:

1. Penelitian Kartika, DT (TT) menyimpulkan bahwa kebiasaan belajar (X1) mempunyai pengaruh yang signifikan terhadap hasil belajar, lingkungan belajar (X2) mempunyai pengaruh yang signifikan terhadap hasil belajar (Y) dan variabel kebiasaan belajar dan lingkungan belajar berpengaruh secara signifikan terhadap hasil belajar siswa kelas $\mathrm{X}$ pada mata pelajaran Ekonomi di SMA Negeri 1 Jombang.

2. Penelitian Santoso dan Rudi (TT) menyimpulkan terbukti bahwa shift malam berpengaruh terhadap penurunan kuantitas dan kualitas tidur secara signifikan, sehingga frekuensi terjadinya gangguan kerja meningkat. Sehingga, hal ini dapat menjelaskan turunnya produktivitas shift malam dibanding shift pagi pada stasiun kerja gunting buang benang di Best Jeans Garment.

3. Penelitian Lestari, I (TT) menyimpulkan bahwa terdapat pengaruh yang signifikan waktu belajar terhadap hasil belajar Matematika siswa, terdapat pengaruh yang signifikan minat belajar terhadap hasil belajar Matematika siswa dan tidak terdapat pengaruh interaksi 
yang signifikan antara waktu belajar dan minat belajar terhadap hasil belajar Matematika siswa.

4. Penelitian Hidayat, A.T (2011) menyimpulkan bahwa dampak shift kerja dirasakan oleh pekerja yang bekerja pada shift pagi dan shift malam. Tetapi, pekerja yang bekerja pada shift malam lebih banyak merasakan keluhan dampak shift kerja dibandingkan saat bekerja shift pagi. Keluhan tersebut dirasakan oleh pekerja terhadap performansi, kesehatan dan psikososial pekerja di PT. Primarindo Asia Infrastructure, Tbk.

5. Penelitian Izzati, R.R (2014) menyimpulkan bahwa waktu perkuliahan berpengaruh positif dan signifikan terhadap tingkat konsentrasi belajar akuntansi biaya 2 pada mahasiswa pendidikan akuntansi angkatan 2011 Universitas Muhammadiyah Surakarta, lingkungan kelas berpengengaruh positif dan signifikan terhadap tingkat konsentrasi belajar akuntansi biaya 2 pada mahasiswa pendidikan akuntansi angkatan 2011 Universitas Muhammadiyah Surakarta dan waktu perkuliahan dan Lingkungan kelas berpengaruh positif dan signifikan terhadap tingkat konsentrasi belajar akuntansi biaya 2 pada mahasiswa pendidikan akuntansi angkatan 2011 Universitas Muhammadiyah Surakarta

6. Penelitian Fatona, dkk. (2015) menyimpulkan bahwa terdapat perbedaan tingkat kelelahan yang signifikansi ( $\mathrm{p}=0,038<0,005$ ) pada perawat shift pagi, sore dan malam pada perawat rawat inap di RS PKU Aisyiyah Boyolali. Karena shift malam mengalami gangguan tidur atau cyrcardyan rhtym, jam kerja yang lebih panjang di bandingkan shift pagi dan sore, jumlah perawat yang lebih sedikit, sehingga mudah mengalami kelelahan.

\section{METODOLOGI}

\section{LangkahPenelitian}

Adapun langkah-langkah dalam penelitian ini dapat dilihat dari Gambar 1.

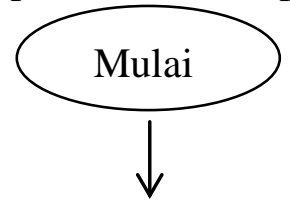

- Studi Lapangan

- Wawancara

- Studi Pustaka 


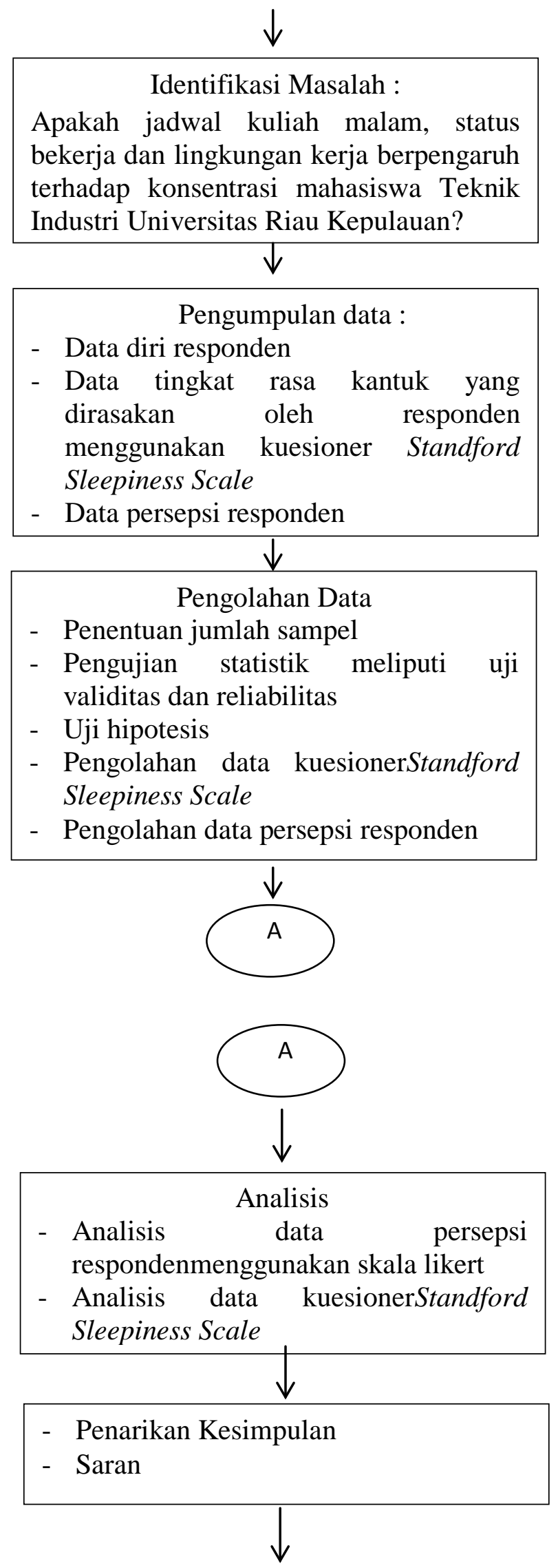




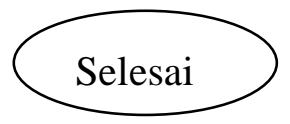

Gambar 1. Tahapan Penelitian

\section{Teknik Pengumpulan Data}

Dalam penelitian ini, teknik pengumpulan data primer dan sekunder adalah sebagai berikut :

1. Studi lapangan, yaitu dengan melakukan pengamatan langsung terhadapkegiatanbelajarmengajarmahasiswaTeknikIndustriUniversitas Riau Kepulauan

2. Wawancara, dengan mengajukan beberapa pertanyaan mahasiswa Teknik Industri Universitas Riau Kepulauan

3. Studi pustaka, yaitu dengan melakukan pengumpulan teori yang bersumber pada jurnal dan buku yang relevan dengan penelitian

4. Kuesioner persepsi dengan penilaian skala likert untuk mengetahui persepsi mahasiswa Teknik Industri Universitas Riau Kepulauan terhadap lingkungan kelas pada saat proses belajar mengajar berlangsung

5. Kuesioner Standford Sleepiness Scale untuk mengetahui pengaruh jadwal kuliah yang diperoleh dari tingkat rasa kantuk yang dialami oleh mahasiswa Teknik Industri Universitas Riau Kepulauan

\section{PEMBAHASAN}

\section{AnalisaPengaruh Status BekerjadenganKonsentrasiMahasiswa}

Dari 80 orang responden, 25\% tidak bekerja (20 orang), sedangkan sisanya sebanyak 75\% (60 orang) adalah bekerja di siang hari dan kuliah di malam hari. Untuk mengetahui ada atau tidaknya pengaruh, dilakukan uji korelasi. Jika koefisien korelasi $>$ r tabel, maka Ha diterima. Jika koefisien korelasi< $r$ tabel, maka Ho diterima Dari hasil perhitungan dengan SPSS versi 22, nilai koefisien korelasi adalah -0.225, sedangkan nilai $\mathrm{r}$ table adalah 0.22. Pada penelitian ini, nilai koefisien korelasi $<\mathrm{r}$ tabel $(-0.225<0.22)$ sehingga terima Ho. Artinya tidak ada pengaruh antara status bekerja dengan konsentrasi mahasiswa. 


\section{Analisa Pengaruh Jadwal Kuliah Malam dengan Konsentrasi Mahasiswa}

Untuk mengetahui pengaruh jadwal kulah malam terhadap konsetrasi mahasiswa dilakukan melalui kuesionerStandford Sleepiness Scale, yang menggambarkan tingkat rasa kantuk yang dirasakan oleh respoden. Dari kuesioner ini, dapat diketahui di jam mana responden sudah mulai merasa mengantuk dan tidak dapat beraktivitas secara penuh.

Jika dilakukan uji korelasi, dimana nilai koefisien relasi adalah $0.194<\mathrm{r}$ tabel (0.22), artinya terima Ho, tidak ada pengaruh antara jadwal kuliah malam dengan konsentrasi mahasiswa. Untuk persebaran tingkat kantuk pada masing-masing jam, pada Gambar 2 terlihat persentase terhadap jawaban responden untuk setiap jam, mulai dari jam 7 pagi - jam 12 malam.

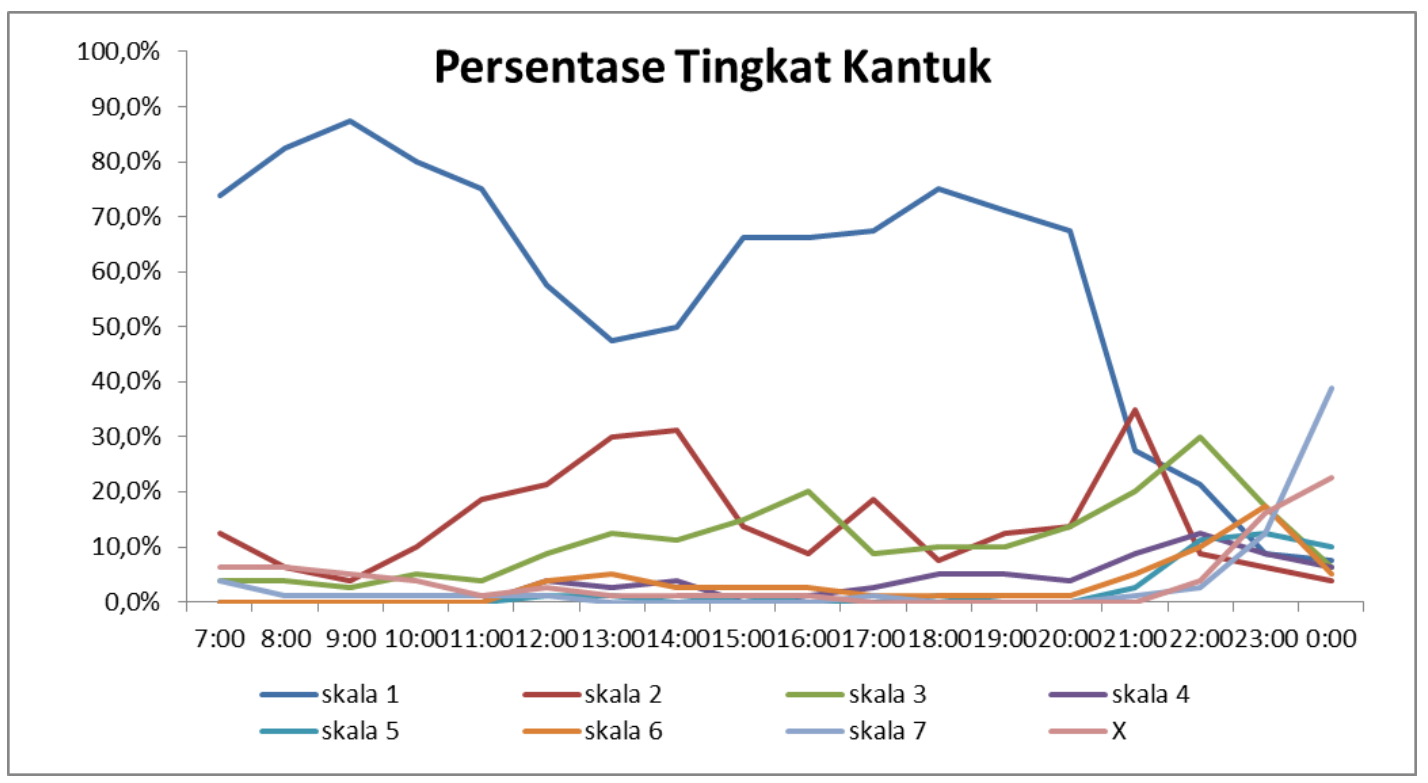

Gambar2.Persentase Tingkat Kantuk

Dari Gambar 2, terlihat bahwa responden yang menjawab skala 1 (masih terjaga) dari jam 7 pagi- jam 10 malam, termasuk banyak. Hal ini dilihat dari nilai persentase terbesar ditemui pada skala 1 untuk masing-masing jam yang ditanyakan. Begitu juga dengan responden yang menjawab 2 (Terjaga, tapi sedikit agak mengantuk), juga banyak, karena jika dilihat dari gambar, persentase terbesar kedua adalah skala 2.

Jika dilihat dari Tabel 1, mulai dari jam 18.00 - 22.00, yang menjawab skala 1 yang artinya masih terjaga, juga memiliki persentase tertinggi, diikuti oleh skala 2 yang artinya 
terjaga, tapi sedikit agak mengantuk. Sehingga, bisa disimpulkan mahasiswa akan tetap terjaga dan tidak mengalami rasa kantuk pada saat mereka kuliah di malam hari.

Tabel 1. Persentase Kantuk Responden Jam 18.00-22.00

\begin{tabular}{|c|c|c|c|c|c|}
\hline Skala & $\mathbf{1 8 : 0 0}$ & $\mathbf{1 9 : 0 0}$ & $\mathbf{2 0 : 0 0}$ & $\mathbf{2 1 : 0 0}$ & $\mathbf{2 2 : 0 0}$ \\
\hline 1 & $75,0 \%$ & $71,3 \%$ & $67,5 \%$ & $27,5 \%$ & $21,3 \%$ \\
\hline 2 & $7,5 \%$ & $12,5 \%$ & $13,8 \%$ & $35,0 \%$ & $8,8 \%$ \\
\hline 3 & $10,0 \%$ & $10,0 \%$ & $13,8 \%$ & $20,0 \%$ & $30,0 \%$ \\
\hline 4 & $5,0 \%$ & $5,0 \%$ & $3,8 \%$ & $8,8 \%$ & $12,5 \%$ \\
\hline 5 & $1,3 \%$ & $0,0 \%$ & $0,0 \%$ & $2,5 \%$ & $11,3 \%$ \\
\hline 6 & $1,3 \%$ & $1,3 \%$ & $1,3 \%$ & $5,0 \%$ & $10,0 \%$ \\
\hline 7 & $0,0 \%$ & $0,0 \%$ & $0,0 \%$ & $1,3 \%$ & $2,5 \%$ \\
\hline $\mathrm{x}$ & $0,0 \%$ & $0,0 \%$ & $0,0 \%$ & $0,0 \%$ & $3,8 \%$ \\
\hline
\end{tabular}

Dan jika dilihat dari status bekerja, dengan membandingkan rasa kantuk pada jam 18.00 - 22.00 untuk responden yang tidak bekeja dapat dilihat dari Tabel 2. Dari tabel ini dapat dilihat bahwa responden yang tidak bekerja yang menjawab skala 1, juga memiliki persentase tertinggi. Jumlah masing-masing responden yang menjawab skala 1 adalah 14 orang pada jam 18.00, 15 orang pada jam 19.00, 16 orang pada jam 20.00, 9 orang pada jam 21.00, 6 orang pada jam 22.00.

Tabel 2. Persentase Kantuk Responden Tidak Bekerja Jam 18.00-22.00

\begin{tabular}{|c|r|r|r|r|r|}
\hline Skala & $\mathbf{1 8 : 0 0}$ & $\mathbf{1 9 : 0 0}$ & $\mathbf{2 0 : 0 0}$ & $\mathbf{2 1 : 0 0}$ & $\mathbf{2 2 : 0 0}$ \\
\hline 1 & $70,0 \%$ & $75,0 \%$ & $80,0 \%$ & $45,0 \%$ & $30,0 \%$ \\
\hline 2 & $0,0 \%$ & $5,0 \%$ & $0,0 \%$ & $20,0 \%$ & $10,0 \%$ \\
\hline 3 & $10,0 \%$ & $5,0 \%$ & $0,0 \%$ & $10,0 \%$ & $25,0 \%$ \\
\hline 4 & $10,0 \%$ & $10,0 \%$ & $15,0 \%$ & $20,0 \%$ & $15,0 \%$ \\
\hline 5 & $5,0 \%$ & $0,0 \%$ & $0,0 \%$ & $0,0 \%$ & $10,0 \%$ \\
\hline 6 & $5,0 \%$ & $5,0 \%$ & $5,0 \%$ & $0,0 \%$ & $0,0 \%$ \\
\hline 7 & $0,0 \%$ & $0,0 \%$ & $0,0 \%$ & $5,0 \%$ & $5,0 \%$ \\
\hline$X$ & $0,0 \%$ & $0,0 \%$ & $0,0 \%$ & $0,0 \%$ & $5,0 \%$ \\
\hline
\end{tabular}

Responden yang bekerja, persentase terbesar juga pada skala 1. Hal ini dapat dilihat dari Tabel 3. Jumlah masing-masing responden yang menjawab skala 1 adalah 46 orang pada jam 18.00, 42 orang pada jam 19.00, 38 orang pada jam 20.00, 13 orang pada jam 21.00, 11 orang pada jam 22.00 . 
Tabel 3. Persentase Kantuk Responden Bekerja

Jam 18.00-22.00

\begin{tabular}{|c|r|r|r|r|r|}
\hline Skala & $\mathbf{1 8 : 0 0}$ & $\mathbf{1 9 : 0 0}$ & $\mathbf{2 0 : 0 0}$ & $\mathbf{2 1 : 0 0}$ & $\mathbf{2 2 : 0 0}$ \\
\hline 1 & $76,7 \%$ & $70,0 \%$ & $63,3 \%$ & $21,7 \%$ & $18,3 \%$ \\
\hline 2 & $10,0 \%$ & $15,0 \%$ & $18,3 \%$ & $40,0 \%$ & $8,3 \%$ \\
\hline 3 & $10,0 \%$ & $11,7 \%$ & $18,3 \%$ & $23,3 \%$ & $31,7 \%$ \\
\hline 4 & $3,3 \%$ & $3,3 \%$ & $0,0 \%$ & $5,0 \%$ & $11,7 \%$ \\
\hline 5 & $0,0 \%$ & $0,0 \%$ & $0,0 \%$ & $3,3 \%$ & $11,7 \%$ \\
\hline 6 & $0,0 \%$ & $0,0 \%$ & $0,0 \%$ & $6,7 \%$ & $13,3 \%$ \\
\hline 7 & $0,0 \%$ & $0,0 \%$ & $0,0 \%$ & $0,0 \%$ & $1,7 \%$ \\
\hline$X$ & $0,0 \%$ & $0,0 \%$ & $0,0 \%$ & $0,0 \%$ & $3,3 \%$ \\
\hline
\end{tabular}

\section{Analisa Pengaruh Lingkungan Kerjadengan Konsentrasi Mahasiswa}

Untuk mengetahui pengeruh lingkungan kerja terhadap konsentrasi mahasiswa pada saat kuliah adalah melalui kuesioner persepsi dengan penilaian dengan skala likert.

Dari hasil uji korelasi, diperoleh nilai koefisien korelasi adalah $0.584>\mathrm{r}$ tabel (0.22), artinya Terima Ha, dengan kesimpulan ada pengaruh antara lingkungan kerja terhadap konsentrasi mahasiswa. Hal ini juga diperkuat dengan beberapa peneliti anter dahulu, yang menyatakan bahwa lingkungan belajar (X2) mempunyai pengaruh yang signifikan terhadap hasil belajar (Y) siswa kelas X pada mata pelajaran Ekonomi di SMA Negeri 1 Jombang. (Kartika, DT (TT)).

\section{Analisa Pengaruh Status Bekerja, Jadwal Kuliah Malam dan Lingkungan Kerja dengan Konsentrasi Mahasiswa}

Dari hasil pengolahan data uji korelasi menggunakan SPSS, diketahui bahwa besarnya hubungan antara status bekerja, jadwal kuliah malam dan lingkungan kerja terhadap konsentrasi mahasiswa yang dihitung dengan koefisien korelasi adalah 0.654. Sedangkan kontrbusi variable status bekerja, jadwal kuliah malam dan lingkungan kerja terhadap konsentrasi mahasiswa adalah 42.8\% sedangkan sisanya $57.2 \%$ dipengaruhi oleh faktor lain. Berdasarkan perhitungan SPSS, diperoleh nilai probabilitas (sig. F change) $=0.00$, dimana nilai sig. F change $=0.00<0.05$, maka keputusannya adalah terima Ha, dengan kesimpulan status bekerja, jadwal kuliah malam dan lingkungan kerja berpengaruh signifikan terhadap konsentrasi mahasiswa. Sehingga diperoleh persamaan sebagai berikut :

$\mathrm{Y}=0.549 \mathrm{X} 1-0.132 \mathrm{X} 2+0,988 \mathrm{X} 3-1,282$

Dimana : $\quad \mathrm{X} 1 \quad=$ jadwal kuliah (tingkat kantuk) 


$$
\begin{array}{ll}
\mathrm{X} 2 & =\text { status bekerja atau tidak } \\
\mathrm{X} 3 & =\text { lingkungan kerja }
\end{array}
$$

Hal ini juga diperkuat dengan beberapa penelitian sebelumnya yang menyatakan waktu perkuliahan dan Lingkungan kelas berpengaruh positif dan signifikan terhadap tingkat konsentrasi belajar akuntansi biaya 2 pada mahasiswa pendidikan akuntan siangkatan 2011 Universitas Muhammadiyah Surakarta (Izzati, R.R, 2014).

\section{KESIMPULAN}

\section{Kesimpulan}

Dari penelitian yang sudah penulis lakukan, maka dapat disimpulkan beberapa hal sebagai berikut :

1. Jadwal perkuliahan malam tidak berpengaruh terhadap konsentrasi mahasiswa Teknik Industri Universitas Riau Kepulauan, dimana nilai koefisien korelasi < r tabel $(-0.225<0.22)$.

2. Status bekerja tidak berpengaruh terhadap konsentrasi mahasiswa Teknik Industri Universitas Riau Kepulauan dimana nilai koefisien korelasi < r tabel $(0.194<0.22)$.

3. Lingkungan kelas berpengaruh terhadap konsentrasi mahasiswa Teknik Industri Universitas Riau Kepulauan dimana nilai koefisien korelasi < r tabel $(0.584$ > 0.22).

4. Jadwal perkuliahan malam, status bekerja dan lingkungan kelas berpengaruh terhadap konsentrasi mahasiswa Teknik Industri Universitas Riau Kepulauan, dimana nilai sig. F change $=0.00<0.05$.

\section{Saran}

Adapun saran yang bias penulis berikan adalah sebagai berikut :

1. Pemberian materi oleh dosen sebaiknya dilakukan dengan ajang diskusi, tidak hanya text book.

2. Materi kuliah juga bisa diberikab dalam bentuk video, sehingga tidak menimbulkan kebosanan pada saat perkuliahan. 


\section{REFERENSI}

Fatona, dkk. 2015. Perbedaan Tingkat Kelelahan Antara Shift Pagi, Sore Dan Malam Pada Perawat Rawat Inap Di RS PKU Aisyiyah Boyolali. Artikel Penelitian. Program Studi Kesehatan Masyarakat Fakultas Ilmu Kesehatan Universitas Muhammadiyah Surakarta

Hamdani dan Santoso.TT. Usulan Penentuan Jadwal Istirahat Dengan Analisis Ritme Circadian Dalam Upaya Meningkatkan Performansi Pekerja Di Best Jeans Garment. Skripsi. Jurusan Teknik Industri Universitas Kristen Maranatha Bandung

Hidayat, AT. 2011. Analisis Pengaruh Shift Kerja Terhadap Beban Kerja Pekerja di PT. Primarindo Asia Infrastructure, Tbk..Tugas Akhir, Program Studi Teknik Industri, FakultasTeknik, Universitas Islam Bandung

Izzati, RR. 2014. Pengaruh Waktu Perkuliahan Dan Lingkungan Kelas Terhadap Tingkat Konsentrasi Belajar Akuntansi Biaya 2 Pada Mahasiswa Pendidikan Akuntansi Angkatan 2011 Universitas Muhammadiyah Surakarta. Naskah Publikasi, Universitas Muhammadiyah Surakarta

Jumiati. 2009. Hubungan Antara Waktu Belajar di Sekolah dan Aktivitas Belajar Siswa dalam Proses Pembelajaran Kimia dengan Prestasi Belajar Kimia Kelas X Semester 1 MAN TEMPEL SLEMAN Tahun Ajaran 2008/2009. Skripsi. Program Studi Pendidikan Kimia, Fakultas Sains dan Teknologi, Universitas Sunan Kalijaga Yogyakarta.

Kartika, D.T. TT. Pengaruh Kebiasaan Belajar Dan Lingkungan Belajar Terhadap Hasil Belajar Siswa Pada Mata Pelajaran Ekonomi Kelas X DI SMA NEGERI 1 Jombang.Skripsi.Fakultas Ekonomi, Unesa, Kampus Ketintang Surabaya

Lestari, I. TT. Pengaruh Waktu Belajar Dan Minat Belajar Terhadap Hasil Belajar Matematika. JurnalFormatif 3(2) 